\author{
Ch. Kyriakopoulos, G. Kamari, I. Kofinas \& D. Phitos
}

\title{
Potentilla greuteriana (Rosaceae), a new species from Mt. Taigetos (S Peloponnisos, Greece)*
}

\begin{abstract}
Kyriakopoulos, Ch., Kamari, G., Kofinas, I. \& Phitos, D.: Potentilla greuteriana (Rosaceae), a new species from Mt. Taigetos (S Peloponnisos, Greece). — Fl. Medit. 28: 351-364. 2018. — ISSN: $1120-4052$ printed, 2240-4538 online.

Potentilla greuteriana Kyriak., Kamari, Kofinas \& Phitos is described as a new species of $P$. sect. Plumosistylae, known from two localities (summit Xerovouni and Langada gorge) on Mt. Taigetos (S Peloponnisos). The habitat of this new Potentilla species is black bituminous, deeply karstified limestone. The closest relative of $P$. greuteriana is $P$. arcadiensis, which is distributed on the neighbouring Mt. Parnonas (E Peloponnisos), but belongs, to $P$. sect. Crassinerviae. The main morphological differences between the new species and its related taxa of $P$. sect. Crassinerviae (P. ulrichii, P. nerimaniae, $P$. davisii) and P. sect. Plumosistylae (P. libanotica and $P$. isaurica) are discussed. Additionally, the conservation status of the new species is provided.
\end{abstract}

Key words: Greek flora, Potentilla, conservation, endemism, taxonomy.

\section{Introduction}

The high diversity of the flora of Greece, rich in endemic and rare plant species, is a consequence of the country's geological history, which has resulted in the formation of a multitude of isolated areas and habitats along the flora's migratory pathways, from Anatolia to central and northern Europe. Peloponnisos is the southern part of the Greek mainland and, at the same time, of the Balkan Peninsula. Mt. Taigetos is one of the main biodiversity hotspots of mainland Greece, with a high percentage of endemic and rare taxa (Phitos \& al. 2009), having strong phytogeographical connections with other mountains of Peloponnisos (examples being the endemic monotypic genus Phitosia crocifolia (Boiss. \& Heldr.) Kamari \& Greuter, Achillea taygetea Boiss. \& Heldr., Crepis heldreichiana (Kuntze) Greuter occurring also on Mt. Parnonas; Globularia stygia Orph. and Teucrium aroanium Boiss. occurring also on Mt. Chelmos, etc.) and of Crete (Herniaria parnassica subsp. cretica Chaudhri,

*Extended and enriched version of the oral presentation given at the International Symposium "Botany at the intersection of Nature, Culture, Art and Science", Selinunte, 28-30 June 2018. 
Ranunculus subhomophyllus (Halácsy) Vierh., occurring also on the Lefka Ori range). The study of these connections is the subject of the first author's PhD thesis.

Several new taxa have recently been described from Mt. Taigetos and its surroundings, such as: Allium orestis Kalpoutz. \& al. (Kalpoutzakis \& al. 2012), Campanula kamariana Kyriak. \& al. (Kyriakopoulos \& al. 2017), Geranium kikianum Kit Tan \& Vold (Tan \& al. 2011) and also Asperula lutea subsp. griseola Greuter, Ballota nigra subsp. anomala Greuter, Lolium scholzii Greuter, Nepeta hystrix Greuter and Trifolium michaelis Greuter (Greuter 2012).

Potentilla L. is one of the largest Rosaceae genera, mostly Holarctic in distribution, though some of its representatives are also found on the mountains of southeast Asia (see Eriksson \& al. 1998; Dobeš \& Paule 2010; Dobeš \& al. 2013). Wolf (1908), the monographer of the genus, recognized ca. 300 Potentilla species and divided the genus into two sections, based on the presence ( $P$. sect. Trichocarpae) or absence (P. sect. Gymnocarpae) of hairs on the carpels, six subsections based on the shape of the pistils and the insertion of the styles, and several lower-ranking groups that are his main units of classification. Wolf's classification was adopted and modified by others, such as Juzepčuk (1941), who upgraded Wolf's subsections to subgenera and his groups to sections, and also Pawłowski (1965), who separated P. subg. Fragariastrum (Ser.) B. Pawł. into two sections (P. sect. Fragariastrum Ser. and P. sect. Plumosistylae B. Pawł.). Ball \& al. (1968), in Flora Europaea, divided the genus Potentilla into 5 subgenera, among them the subg. Fragariastrum (Heister ex Fabr.) Reichenb., which was further divided into two sections, i.e. sect. Fragariastrum and sect. Plumosistylae, according to Pawłowski (1965). Later, Soják (1987) divided Wolfs' Potentilla sect. Trichocarpae Th. Wolf into 19 sections, based on flower and anther structure and style shape. Moreover, by using molecular phylogenetic methods, a better understanding of the origin of subfamily Rosoideae Arn. of Rosaceae Juss. and of Potentilla itself has been achieved (see Eriksson \& al. 1998, 2003; Potter \& al. 2007; Lundberg \& al. 2009).

Recently, Soják (2008), while presenting a new genus-level classification of the Potentilleae Sweet, suggested its division into two subtribes, i.e. Potentillinae J. Presl and Fragariinae Torr. \& A. Gray, based on morphological characters, which is consistent with the phylogenetic tree by Eriksson \& al. (1998), who proposed that Potentilla contains ca. 485 species of annual, biennial and perennial herbs, several of hybridigenous origin. According to phylogenetic reconstructions (Dobeš \& Paule 2010), Potentilla s. str. comprises mainly herbaceous species, representing 24 of the 31 series distinguished by Wolf (1908).

In Greece, there are 26 taxa of Potentilla (eight in Peloponnisos), three of which are endemic. These include the submontane Potentilla arcadiensis Iatroú (Iatroú 1985) from Mt. Parnonas, E Peloponnisos, and two mountain species, P. kionaea Halácsy (Halácsy 1888) from Mt. Giona, Sterea Hellas and P. deorum Boiss. \& Heldr. (Boiss. \& Heldr. 1856) from Mt. Olimbos, NC Greece (Strid 1986).

In July 2011, Ioannis Kofinas, during a visit to the Langada climbing area of Mt. Taigetos, noticed an interesting Potentilla chasmophyte with robust and richly leafy flowering stems, growing on vertical rocks. On August of the following year (Aug 5, 2012) during a field survey by the first author on $\mathrm{N}$ Taigetos, west of the Xerovouni peak $(1523 \mathrm{~m})$, an additional, larger population with the same characteristics was found. The substrate in the two above localities, where this species grows, is black bituminous, deeply karstified limestone. Macroscopically, it resembles $P$. arcadiensis ( $P$. sect. Crassinerviae), endemic to the neigh- 
bouring Mt. Parnonas (SE Peloponnisos), from which, however, it differs morphologically in several features, such as its strongly supine flowering stems and visibly compact inflorescences with short pedicels, attributes that rather point to representatives of $P$. sect. Plumosistylae, such as P. libanotica Boiss. and P. isaurica (P. H. Davis) Pawł. from S Anatolia.

In this paper we describe these Potentilla plants from Mt. Taigetos as a new species, which is related to the neighboring $P$. arcadiensis (P. sect. Crassinerviae) from Mt. Parnonas and also to the Anatolian taxa P. libanotica Boiss. (Boissier 1872) and P. isaurica B. Pawł. (Pawłowski 1965) of $P$. sect. Plumosistylae. We also clarify the relationships of the new species with other close relatives.

\section{Materials and methods}

For the description of the new species, both living and dried material of all related Potentilla taxa from Greece and S-SE Anatolia \& E Mediterranean area was used. The herbarium material that we also used for comparisons is deposited in the following Herbaria: B, E, L, P, Herb. Phitos \& Kamari (UPA) and UPA (acronyms follow Thiers 2018).

Morphological observations were carried out under a Zeiss stereomicroscope. For taxonomic identification, scientific papers and floras (Boissier 1872; Juzepčuk 1941; Pawłowski 1965; Ball \& al. 1968; Schiman-Czeika 1969; Peşmen 1972; Iatroú 1985; Soják 1987, 2008; Duman \& Mill 1999; Tan \& Iatroú 2001; Parolly \& Nordt 2002) were used. The collection localities for all species were georeferenced and the distributions were mapped using the freeware GIS software QGIS 2.18 (2017), and Image Editor GIMP 2.8.22.

A detailed comparison between the new species and other morphologically related taxa is given in Table 1 .

\section{Results}

Potentilla greuteriana Kyriak., Kamari, Kofinas \& Phitos sp. nov. (Figs. 1 \& 2).

Diagnosis: Potentilla greuteriana differs from its related Greek endemic P. arcadiensis by the absence of digitate leaves, longer petioles, different indumentum of 1.2-1.5 mm long glandular and 1.0-1.2 mm long simple hairs, larger leaflets, longer stipules and auricles of the basal leaves, dense inflorescences with much shorter pedicels (7-10 mm against 15-35 mm long), glabrous petals, and usually pubescent to almost plumose, rarely glabrous, persistent styles.

$P$. greuteriana is related to the members of $P$. sect. Plumosistylae. It differs from its closest relatives in that section, $P$. libanotica and $P$. isaurica, by its indumentum (long glandular and slightly shorter simple hairs), the longer leaflets, shorter epicalyx segments and petals, anther shape (ovate to obovate rather than globose) and smaller achenes. Additionally, it differs from P. libanotica by the number of leaflet teeth (5-6 rather than 69) and seed hairiness (apex pilose to pubescent) and from $P$. isaurica by the obtuse rather than acute teeth and the shape of the petals (obovate to ovate instead of elliptic). 


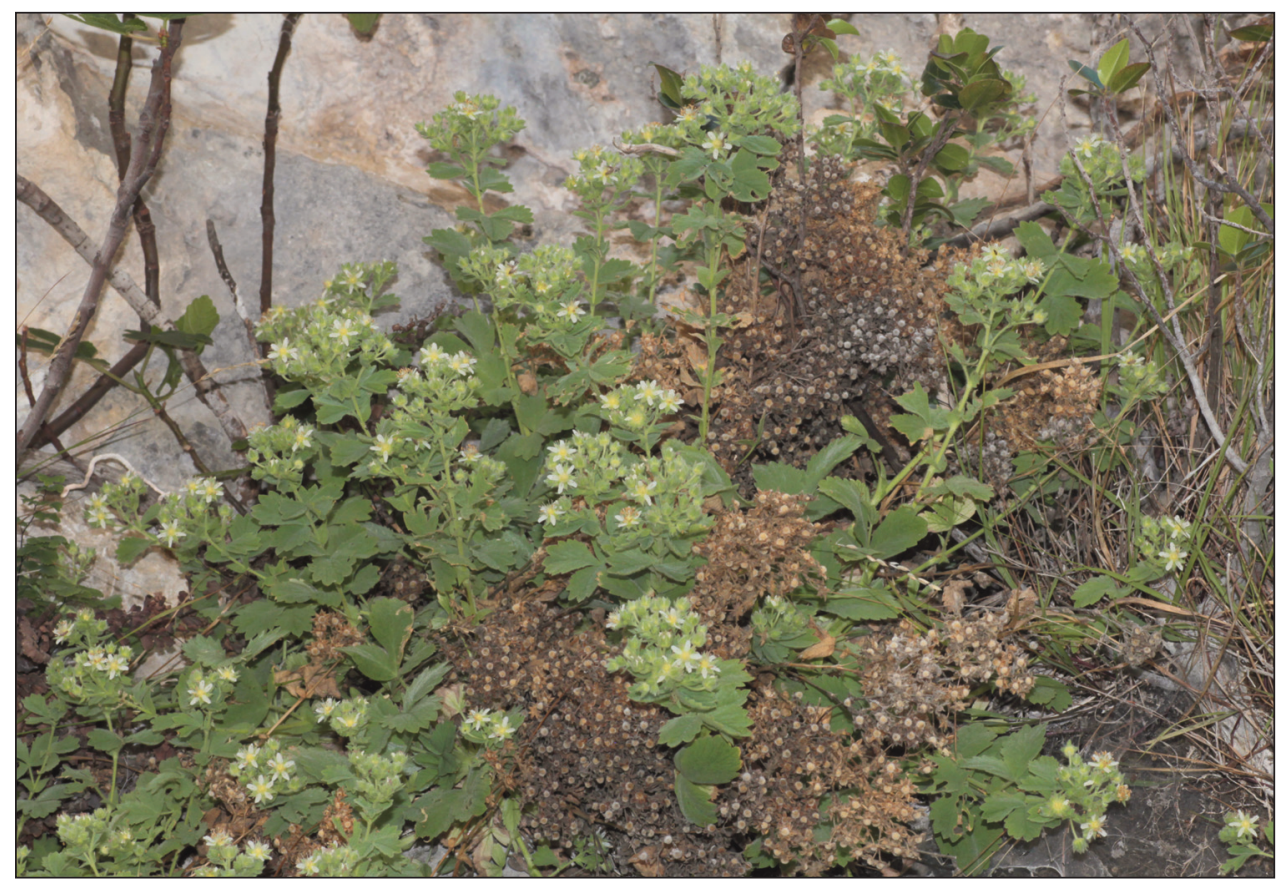

Fig. 1. Individual of Potentilla greuteriana from its locus classicus on the summit Xerovouni of North Taigetos.

Type: Greece: S Peloponnisos: Nomos Arkadias: Mt. N Taigetos, W-SW of Xerovouni summit, $37^{\circ} 09^{\prime} \mathrm{N}, 22^{\circ} 13^{\prime} \mathrm{E}$, alt. c. $1150 \mathrm{~m}$, with Pinguicula cristallina subsp. hirtiflora, Campanula asperuloides, Teucrium aroanium etc., on vertical karstified limestone rocks, 9 Jul 2017, Ch. Kyriakopoulos 2334 (Holotype: Herb. Phitos \& Kamari, UPA!). Isotypes: ACA! and PAL-Gr!

Description: Perennial, densely tufted to pulvinate. Flowering stems several, decumbentascending, 8-24(-27) $\mathrm{cm}$ long, 1-2 $\mathrm{mm}$ in diameter, longer than basal leaves, densely clothed with 1.2-1.5 mm long, erect to erect-patent glandular hairs and equally numerous, up to 1.0-1.2 $\mathrm{mm}$ long, patent simple hairs. Leaves in rosettes, long-petiolate, trifoliolate, green to yellowish-green, concolorous, smooth, almost sericeous, with apressed long hairs along the nerves, and a mixture of short and long hairs to the rest of the surface, with scattered 2-4 celled, $<0.5$ $\mathrm{mm}$ long glandular hairs along the leaflet margins; leaflets obovate, cuneate at base, terminal: $(20-) 25-38(-44) \times(10-) 15-28 \mathrm{~mm}$, lateral: $(20-) 22-35 \times(10-) 15-26 \mathrm{~mm}$, terminal tooth of leaflets equalling or shorter than the first lateral teeth; margins crenate (-serrate), lateral teeth 46(-7) on either side; petiole 3-6(-7.2) cm long, with erect glandular hairs up to $2 \mathrm{~mm}$ long and patent-erect simple hairs up $1 \mathrm{~mm}$ long (length ratio almost 1:2); stipules lanceolate-acuminate, 2.0-2.4 $\times 0.6-0.7 \mathrm{~cm}$, with auricles $0.8-1.3 \mathrm{~cm}$ long, with simple apressed hairs, up to $0.8 \mathrm{~mm}$ long and shorter, scattered glandular along both margins, green, becoming yellowish-green at 

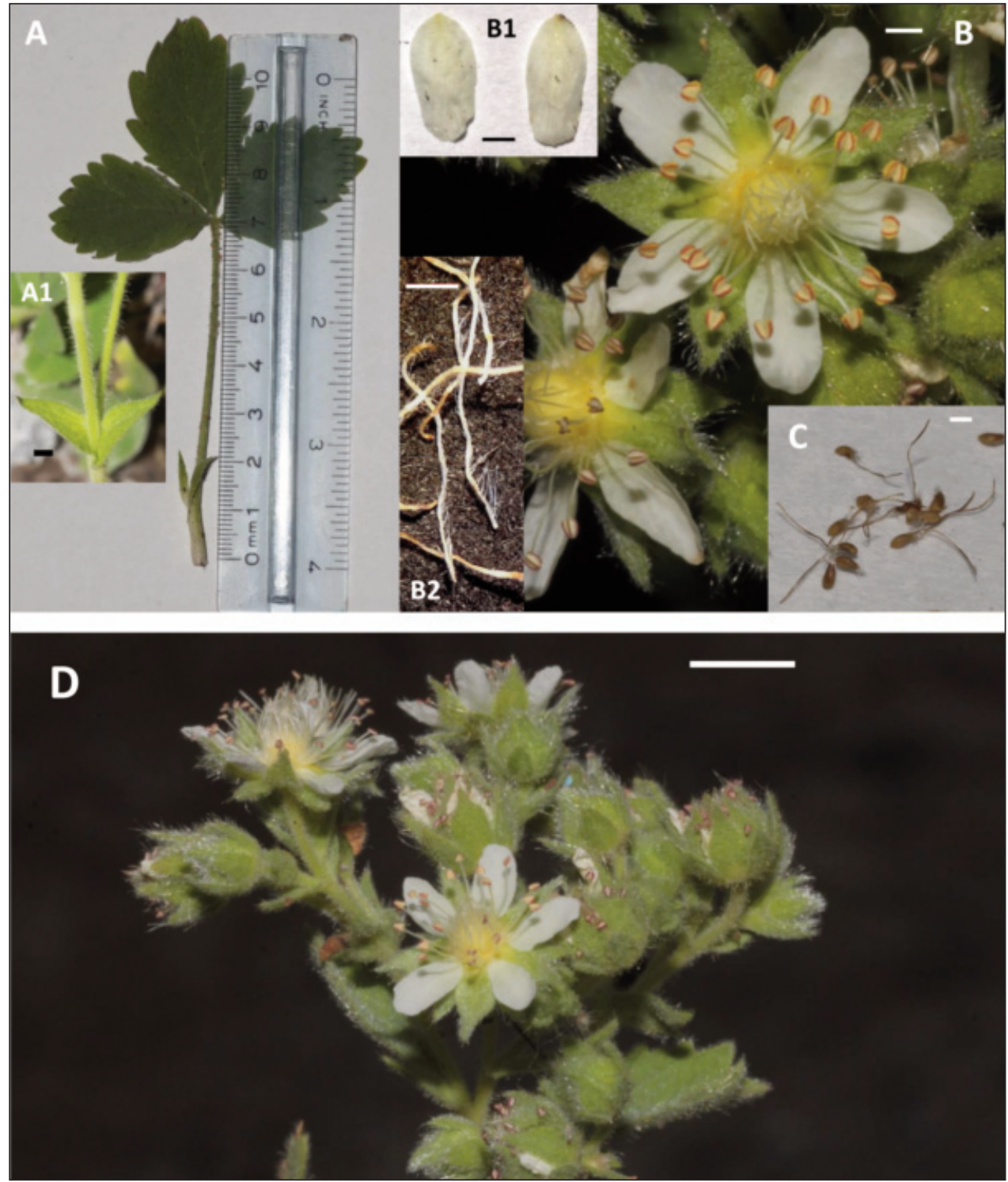

Fig. 2. Potentilla greuteriana sp. nova: A, basal leave, petiole, stipules; A1, stipules of cauline leaves; B, flower; B1, petals; B2, styles; C, achenes with persistent styles; D, inflorescense. - Scale bars A$\mathrm{C}=1 \mathrm{~mm} ; \mathrm{D} .=5 \mathrm{~mm}$.

the base. Cauline leaves similar but smaller, with green, broader stipules, leaflets with 4-5 teeth, the larger 27-32(-37) $\times 18-22(-26) \mathrm{mm}$, in the middle of the stems (4th-5th from the bracts), diminishing upwards. Inflorescence a compact, terminal, rather dense cyme, ca. 12-30(-40) flowered, densely to moderately villous with long $(\leq 1.2 \mathrm{~mm})$ patent simple hairs and erect glan- 
dular ( $\leq 1.2-1.5 \mathrm{~mm}$ long). Bracts foliaceous, usually less than 1.5-2.0 $\times 0.7-1.1 \mathrm{~cm}$, with up to two teeth each side. Pedicels 7-10(-15) mm long, slender (diameter 0.5-0.8 mm). Flowers relatively small. Epicalyx segments 5, narrowly ovate-lanceolate, acute, ca. 3-3.5 × 1-1.5 mm, not visible in front view of the perianth, with patent simple and sparse, short glandular hairs. Calyx densely sericeous-villous, (7-)8-9(-11) $\mathrm{mm}$ in diam., moderately accrescent in fruit; divided into 5 sepals $(4-4.5 \times 1.5-2.0 \mathrm{~mm})$, indumentum with long erecto-patent simple hairs chiefly on the abaxial face, slightly larger than the epicalyx segments, cuneate to truncate at base. Petals white, with an obovate to obovate-oblong, rounded to broadly obtuse apex and a rounded to cuneate base, slightly longer than the sepals, 3.2-4.5 × 2.5-3 mm, glabrous. Stamens ca. 30; filaments 2.5-3.5 mm long, pilose in proximal 5/6, more loosely so in the distal $1 / 2$, anthers pale yellowish with reddish margins, ovate to obovate, $0.4-0.5 \times 0.3 \mathrm{~mm}$. Style subapical, usually pubescent (for 1/3-1/2 of its length) or rarely glabrous, ca. 3-4 mm long, filiform (nematostylous). Nutlets ivory, kidney-shaped, distinctly compressed, 0.9-1.3 $\times 0.9 \mathrm{~mm}$, smooth, apex pilose, margin narrowly winged, with persistent style.

Phenology: Potentilla greuteriana flowering from mid-June to mid-August. Fruiting from late August to the end of September.

Distribution and Habitat: Potentilla greuteriana is a narrow endemic of Mt. Taigetos (S Peloponnisos). Based on current data, its area of occurrence (Fig. 4) is limited to two, disjunct areas, on the rocky systems of North Taigetos, west of the summit Xerovouni and at suitable habitats of Langada gorge, in Central Taigetos. P. greuteriana is a typical chasmophyte. It grows on shady or half-shaded places, on vertical rocks, which consist of gray to black bituminous (containing solid organic ingredients), karstified limestone, capable of providing the flora that grows on it with the needed water (Fig. 3). The species appears to have adapted to the particular features of that limestone substrate, its dense root network effectively penetrating and absorbing water and nutrients from it.

Potentilla individuals on the Xerovouni summit grow at an altitude of ca. 1150-1200 m in N-NE exposure, while those of the Langada climbing area grow at an altitude of 750$800 \mathrm{~m}$ in S-SE exposure (Fig. 3).

Together with Potentilla greuteriana on the summit of Xerovouni, N Taigetos, there also grows the carnivorous Pinguicula crystallina subsp. hirtiflora (Ten.) Strid (this is the first report of its presence on N Taigetos, which constitutes its southernmost known occurrence) and, additionally, some Peloponnese endemic taxa, e.g. Globularia stygia, Teucrium aroanium, Campanula asperuloides (Boiss. \& Orph.) Engl., Minuartia pichleri Maire \& Petitm, etc.

In Langada gorge, Potentilla greuteriana co-exists with the following endemic taxa: Asperula boryana, Campanula asperuloides, Carum depressum Hartvig \& Kit Tan, Inula verbascifolia subsp. methanaea (Hausskn.) Tutin and Stachys candida Bory \& Chaub., whereas the local endemic Hypericum taygeteum Quézel \& Contandr. is found nearby.

Conservation status: Potentilla greuteriana is a narrow endemic with a very limited area of occurrence in specialized habitats. Based on in-situ observations, it appears that a necessary condition for the species survival is the uninterrupted supply of water through the capillaries of the calcareous rocks on which it occurs. Possible changes of 

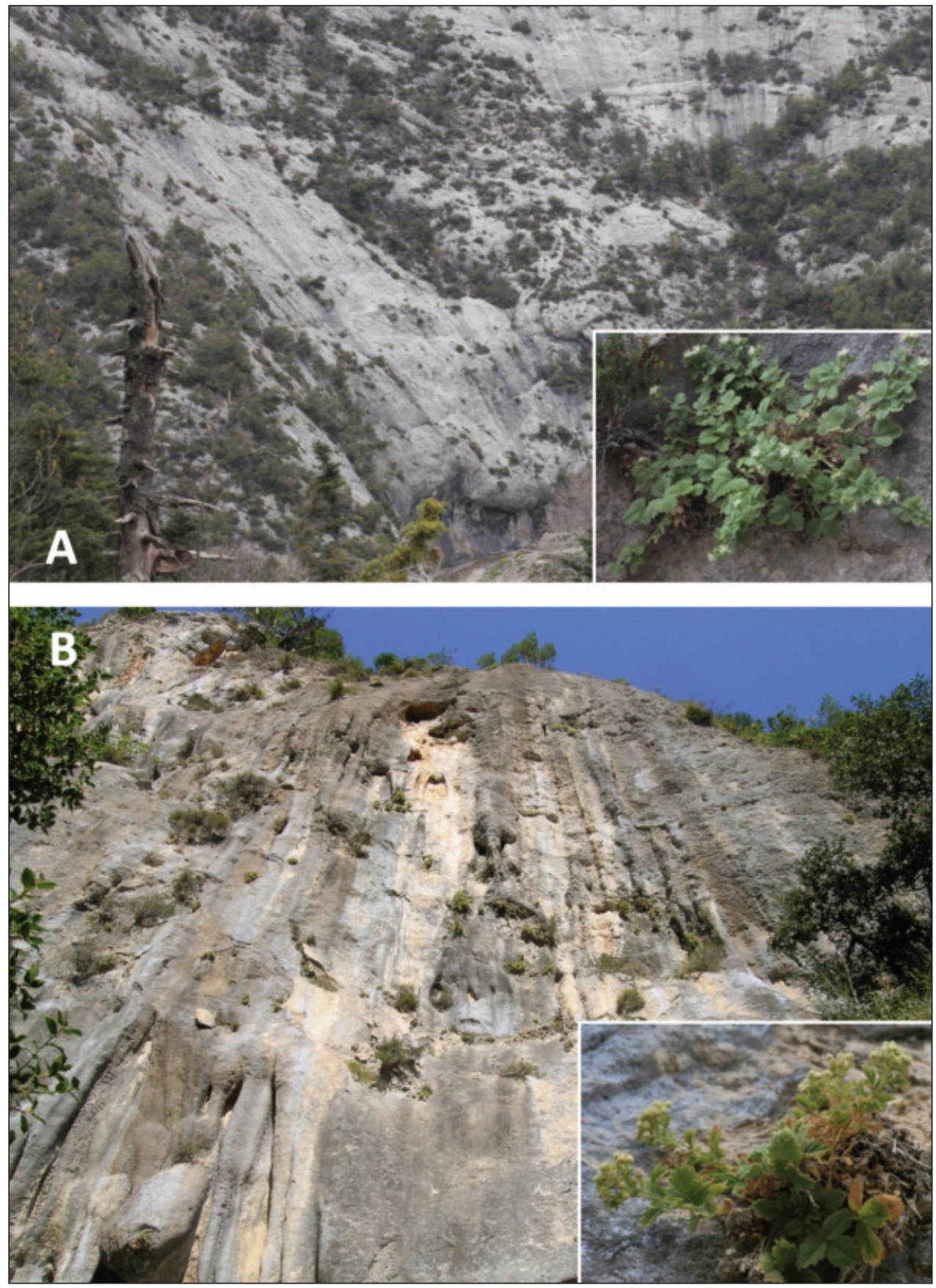

Fig. 3. Biotopes of the typical chasmophyte species Potentilla greuteriana: $\mathbf{A}$, the summit area of Mt. Xerovouni (locus classicus) of the north Taigetos and $\mathbf{B}$, the climbing area of Langada gorge in central Taigetos. 
water potential of the karstified limestone systems, on which it grows, may cause a population decline. The subpopulation of the Langada area occupies an area of less than 300 $\times 50 \mathrm{~m}\left(<1 \mathrm{~km}^{2}\right)$ and consists of 100-150 mature individuals, while the subpopulation of $\mathrm{N}$ Taigetos (Xerovouni) develops over an area of $250 \times 30 \mathrm{~m}\left(<1 \mathrm{~km}^{2}\right)$ and consists of 400-600 mature individuals. Moreover, the subpopulation of the former locality is potentially threatened by the fact that the area is used as a climbing field. Following the IUCN (2017) criteria, the taxon should be categorized as Endangered (EN), on the basis of its restricted distribution [restricted, extent of occurrence $\left(\mathrm{EOO}<100 \mathrm{~km}^{2}\right)$ and area of occupancy $\left.\left(\mathrm{AOO}<100 \mathrm{~km}^{2}\right)\right]$, the fact that no more than 750 mature individuals were counted, and the high possibility of erosion of the substrate as a result of human activities (climbing) [B1ab(i,ii,iii,iv), B2ac(i,ii,iii,iv)].

Etymology: The species is named after Werner Greuter, Professor Emeritus of Plant Systematic, Nomenclature and Phytogeography of the world flora and especially expert of the Greek and Cretan flora, for his 80th birthday.

Discussion: Potentilla greuteriana is one more new stenoendemic taxon of Mt. Taigetos (S Peloponnisos). It is related to the Greek endemic P. (sect. Crassinerviae) arcadiensis from Mt. Parnonas (SE Peloponnisos), but also to the Anatolian endemics P. isaurica \& P. libanotica (P. sect. Plumosistylae), which spread around S Turkey, Syria and Lebanon (see Fig. 4).

The only close relative of Potentilla greuteriana in Greece is P. arcadiensis (Fig. 5), which, however, according to Iatroú (1985), is a distinct and geographically isolated

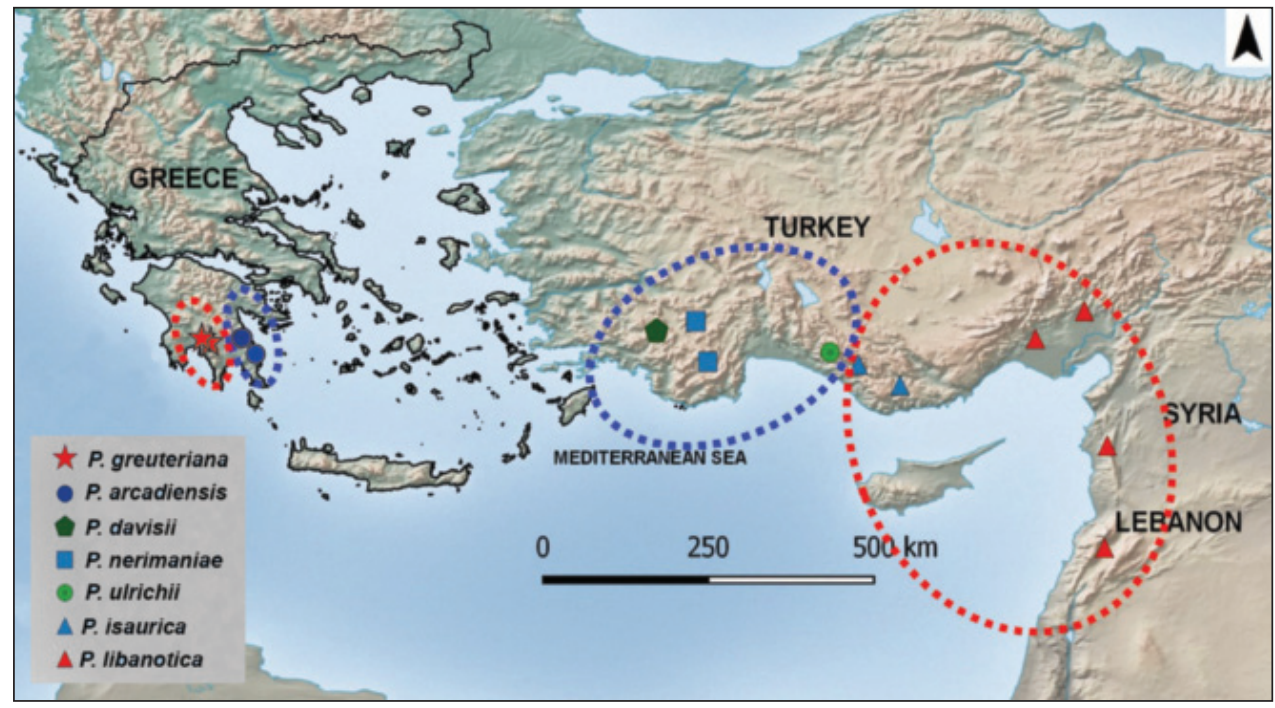

Fig. 4. Distribution map of the two Potentilla Greek endemic species and their related species in S \& SW Anatolia, Syria and Lebanon. 


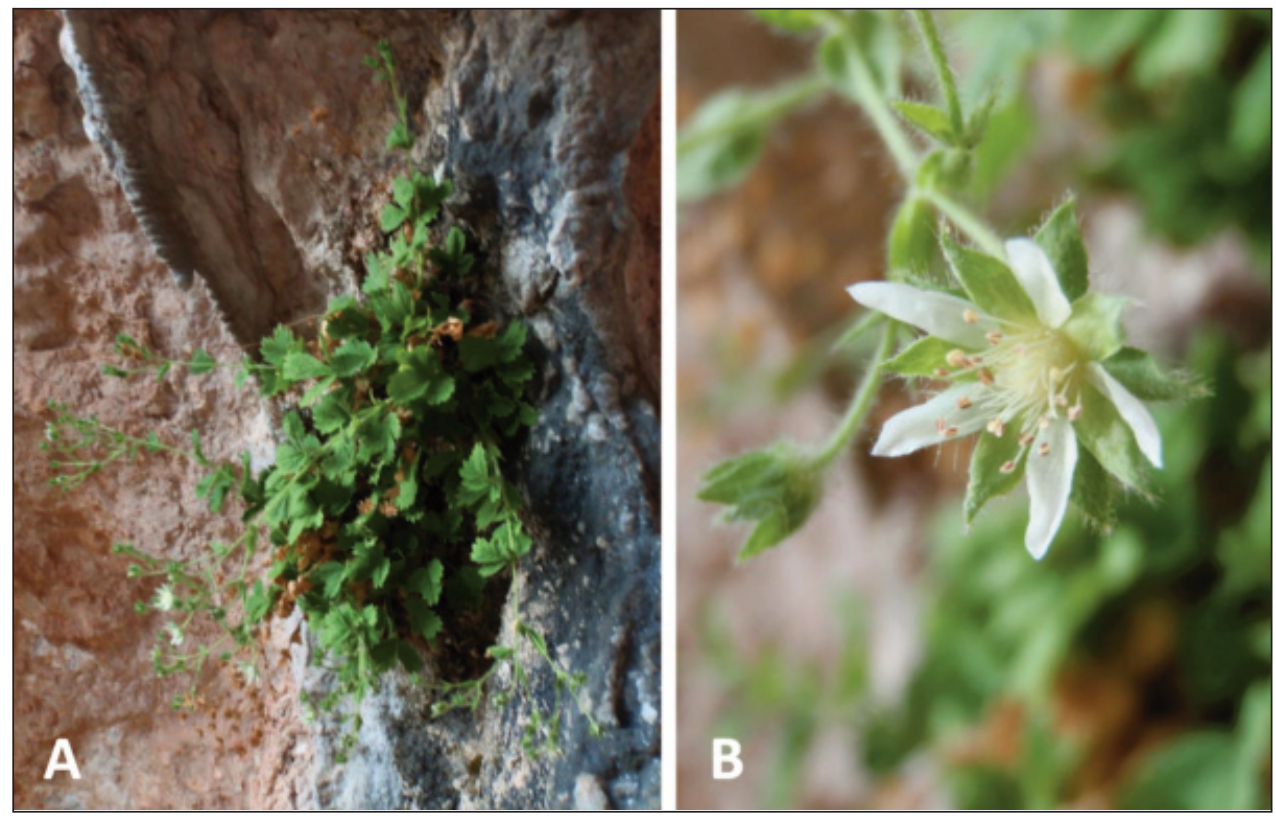

Fig. 5. Potentilla arcadiensis from its locus classicus at the Monastery of Elona, Mt. Parnonas: A, individual; $\mathbf{B}$, inflorescense and flower.

species without any other close relatives in Greece. $P$. arcadiensis, in contrast to $P$. greuteriana, exhibits 1-2 digitate basal leaves, a feature that, according to Iatroú (1985), "suggests an intermediate position between the species of the $\mathrm{E}$ and $\mathrm{W}$ Mediterranean area". The diploid chromosome number of $P$. arcadiensis, $2 n=14$, is an additional character of the representatives of the Crassinerviae group, such as $P$. crassinervia Viv., $P$. valderia L. and P. haynaldiana Janka (Contadriopoulos 1962; Baltisberger 2006). Based on this chromosome number, along with the hairlessness of styles and some other morphological features, Iatroú (1985) suggested that $P$. arcadiensis belongs to $P$. sect. Fragariastrum Ser., group Crassinerviae.

Additionally, P. nerimaniae Duman and P. davisii Mill \& Duman, described by Duman \& Mill (1999) from S \& SW Anatolia, were also classified in P. (subg. Fragariastrum) sect. Crassinerviae (Th. Wolf) Juz. The taxa of $P$. sect. Crassinerviae differ from those of $P$. sect. Plumostistylae mainly by the predominant indumentum of simple hairs, \pm hiding the much shorter glandular hairs, loose inflorescences, flowers with long pedicels, pilose filaments, achenes with scrobiculate-reticulate surface etc (see Table 1).

Potentilla ulrichii Parolly \& Nordt, which was described more recently (Parolly \& Nordt 2002), also from S Anatolia, was classified in $P$. sect. Crassinerviae and placed in the $P$. nerimaniae group, together with $P$. davisii and $P$. arcadiensis. This species is also considered a close relative of $P$. libanotica and $P$. isaurica (Table 1).

However, P. libanotica and P. isaurica, together with $P$. saxifraga De Not. (a taxon growing in the lowland and the middle altitudinal level of Mediterranean Alps) were clas- 


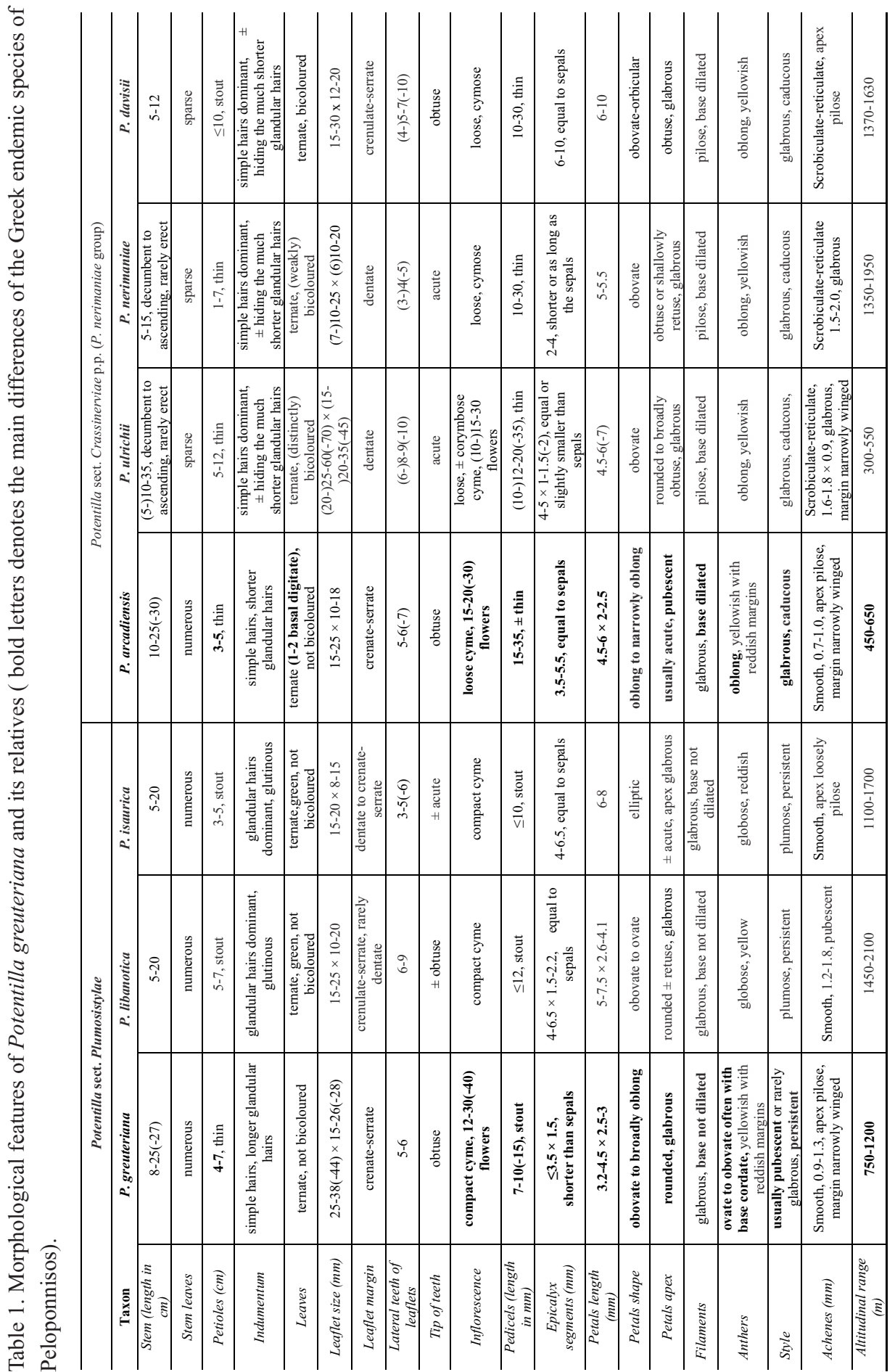


sified by Pawłovski (1965) in P. sect. Plumosistylae because of their main morphological features, which are the non-deciduous, persistent and plumose (for up to $3 / 4$ ) styles and the almost globose anthers. The same classification is also followed by Soják (1987), who added to the morphological features of $P$. sect. Plumosistylae the slender filaments not dilated at the base, and stems with numerous leaves. According to the above characters, $P$. greuteriana probably belongs to $P$. sect. Plumosistylae. The main morphological features commonly found in P. sect. Plumosistylae, are: numerous leaves on flowering stems (with 58 unequal leaves, the largest in the middle of the stems), short-pedicellate flowers [length 0.6$1.2(-1.5) \mathrm{cm}]$, glabrous filaments, glabrous petals, subterminal, filiform, persistent styles pubescent for 2/3-3/4 of their length, and smooth achenes (Table 1).

Potentilla greuteriana also shows some similarities to $P$. arcadiensis of $P$. sect. Crassinerviae, from which, however, it differs mainly by the bigger size [(25-38(-44) $\times 15-26(-$ 28) $\mathrm{mm}$ ] of the always trifoliolate leaves; the indumentum of the flowering stems and pedicels, which consists of longer (12-15 mm) glandular and shorter $(10-12 \mathrm{~mm})$ englandular hairs; the longer [10-18(-24) $\mathrm{mm}]$ stipules of the basal leaves, with significantly longer $(8-12 \mathrm{~mm})$ auricles; the epicalyx segments significantly shorter than the sepals; the shorter, glabrous petals, the styles usually pubescent for 2/3-3/4 of their length, persistent on the achenes; and more significantly the shorter [7-10(-15) $\mathrm{mm}]$ pedicels and the compact inflorescences (see Table 1).

Kechaykin \& Shmakov (2016) in their revision of Potentillinae J. Presl, using molecular data and based on morphological differences, classified Fragariastrum Heist. ex Fabr. and Tormentilla L. as separate genera and included in them several Potentilla species. For example, $P$. arcadiensis and some of its Anatolian relatives are included in Fagariastrum sect. Plumosistylae (Pawłowski) Kechaykin \& Shmakov (P. sect. Plumosistylae Pawłowski). This new classification of $P$. arcadiensis is uncertain because it does not display any of the key characters of $F$. sect. Plumosistylae, such as: anthers globose; style persistent in fruit and plumose at least in its lower half etc. (see: Pawłowski 1965: 79; Ball \& al. 1968: 47). Detailed molecular data from P. arcadiensis and P. greuteriana, as well as from taxa of both $P$. sect. Plumosistylae and . sect. Crassinerviae, could help elucidate the relationships of the two Greek endemic Potentilla species and their relatives.

Identification key to the Greek and the S-SE Anatolian \& E Mediterranean Potentilla species related to $P$. greuteriana.



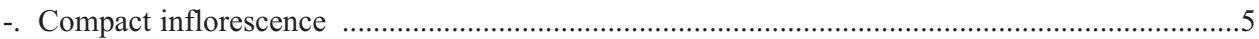

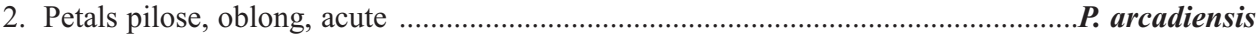

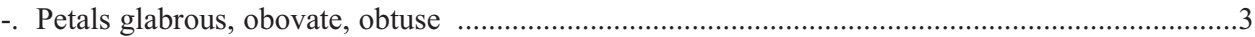

3. Achenes pubescent, leaflet margins crenulate to serrate ……......................................P. davisii

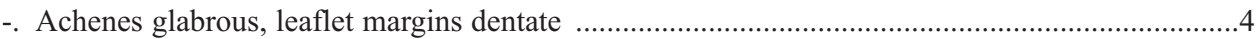

4. Lateral teeth of leaflets (3-)4(-5), epicalyx segments $2-4 \mathrm{~mm}$ long ............................ nerimaniae

-. Lateral teeth of leaflets (6-)8-9(-10), epicalyx segments 4-5 mm ................................... ulrichii

5. Petal shape elliptic, lateral teeth of leaflets 3-5(-6), acute .............................................. isaurica

-. Petal shape obovate to ovate, lateral teeth of leaflets $5-9$, obtuse ............................................... 6

6. Lateral teeth of leaflets 5-9, achenes pilose, styles plumose ................................... P. libanotica

-. Lateral teeth of leaflets 5-6, achenes pilose only at the apex, styles usually pubescent or rarely glabrous 


\section{Specimens seen}

\section{Potentilla greuteriana}

GREECE: S Peloponnisos: Prov. Arkadias: Mt. N Taigetos, W-SW of Xerovouni summit, $37^{\circ} 09^{\prime} \mathrm{N}$, $22^{\circ}$ 13' E, 1150-1200 m, 5 Aug 2012, Ch. Kyriakopoulos \& Chr. Papagiannopoulos 1300 (Herb. Phitos \& Kamari, UPA); ibidem: 24 Jun 2013, Ch. Kyriakopoulos 1530 (Herb. Phitos \& Kamari, UPA); ibidem: 23 Juy 2013, Ch. Kyriakopoulos 1697 (Herb. Phitos \& Kamari, UPA); ibidem: 16 Jul 2015, Ch. Kyriakopoulos 2240 (Herb. Phitos \& Kamari, UPA); ibidem: 24 Sept 2015, Ch. Kyriakopoulos 2249 (Herb. Phitos \& Kamari, UPA); ibidem: 11 May 2016, Ch. Kyriakopoulos 2264 (Herb. Phitos \& Kamari, UPA); ibidem: alt. c. 1150 m, with Pinguicula cristallina subsp. hirtiflora, Campanula asperuloides, Teucrium aroanium etc, on vertical karstified limestone rocks, 9 Jul 2017, Ch. Kyriakopoulos 2334 (Holotype: Herb. Phitos \& Kamari, UPA; Isotypes: ACA and PAL-Gr).

GREECE: S Peloponnisos: Prov. Lakonias: Mt. Taigetos, Langada gorge, on vertical limestone cliffs, $37^{\circ} 04^{\prime}$ N, $22^{\circ} 18^{\prime}$ E, 750-800 m, 31 Jul 2011, Ch. Kyriakopoulos 895 (Herb. Phitos \& Kamari, UPA); ibidem: 22 Jun 2012, Ch. Kyriakopoulos \& E. Kartsonas 968b, (Herb. Phitos \& Kamari, UPA); ibidem: 25 Jun 2012, Ch. Kyriakopoulos 1103 (Herb. Phitos \& Kamari, UPA); ibidem: with Campanula asperuloides, 5 Aug 2012, Ch. Kyriakopoulos \& Chr. Papagiannopoulos 1310 (Herb. Phitos \& Kamari, UPA).

\section{Potentilla arcadiensis}

GREECE: E Peloponnisos: Arkadia: Mt. Parnonas, in declivibus orientalibus montis Parnon; ad Monasterium Elona, in rupestribus calc., alt. c. 550 m, 7 Jul 1983, G. Iatrou 1911 (Holotype: UPA); ibidem: the nunnery of Agios Nikolaos Sintzas, c. $6.4 \mathrm{~km}$, SW the village of Leonidion, steep, calcareous rocks mostly to the $\mathrm{N}$ and SE of the nunnery, $37^{\circ} 0.8^{\prime} \mathrm{N}, 22^{\circ} 49^{\prime} \mathrm{E}$, alt. 550-600 m, 30 May 2003, Th. Constantinidis \& E. Kalpoutzakis 10677 (Herb. Phitos \& Kamari, UPA); ibidem: monastery of Panagia Elona, vertical limestone cliffs after the monastery entrance, $37^{\circ} 09^{\prime} \mathrm{N}, 22^{\circ} 45^{\prime}$ E, alt. 500 m, 10 Jul 2016, Ch. Kyriakopoulos 2293 (Herb. Phitos \& Kamari, UPA).

\section{Potentilla davisii}

TURKEY: C2 Denizli: Acipayam, Bozdag, Olukbaîi, above Geyran Yayla, 1450 m, rocks, 4 Aug 1997, Aytaç 7648 (Isotype E00075639); Bozdag, near Geyran Yayla, 4500 ft, rocks, 16 Jul 1947, Davis 13334 (Paratype E00146056); ibidem: 5000-5500 ft, Davis 13435 (Paratype E00146055).

\section{Potentilla isaurica}

TURKEY: C2 Antalya: Vil. Antalya (Isauria): Kargi Chai, between Durbanas and Derince valley, in cliffs, fl. white, 25 Aug 1947, Davis 14466 (Holotype E00010703, Paratype K000762317);

C4 Antalya: Alanya, Dimçayi vadisi, 1200 m, 10 Oct 1992, Duman 4677 \& Karaveliogullari (E00077481).

\section{Potentilla libanotica}

LEBANON: Liban, in mount Libano, 1837, Aucher-Eloy 1457 (P03342030); In declivita Libani borealis occidentalibus, prope pagum Ehden, 1450-1700 m, 30 Jun-2 Jul 1910, Bornmüller 11766 (E00146058); Bcharré [sentier des Cèdres] (Liban), 1800 m, 14 August 1927, Gombault 17 (P03342020); Mt. Lebanon, Akoura, 2000 m, 30 Jul 1932, Louis [Frères Maristes d'Alep] s.n. (P04173512); ibidem: Aqoura, 31 Jul 1932, Gombault 1981 (P03342018, P03342019, P03342021, P03342018).

SYRIA: Hadret, 1822, Ehrenberg 322 (L.1901646); Syria, 1846, Pinard s.n. (E00409399).

TURKEY: C5 Içel: Kapudschi Dere, an Felsen, 1896, Siehe 643 (E00146059); Osmaniye: Amanus: Mont de Düldül, 1500-2000 m, 15 Aug 1911, Haradjian 3890 (E00409400). 


\section{Potentilla nerimaniae}

TURKEY: C2 Antalya: Elmali, Çiglikara, 1900-1950 m, on calcareous rocks, 1 Aug 1995, Duman, Ekici \& Duran (Duman 5978), (Isotype E00009314).

\section{Potentilla ulrichii}

TURKEY: C3 Antalya: Abzweig der Straße Manavgat - Akseki, nahe Ahmetler SW Muratiçi, 500 m, überhängende, schattige Kalkwand, Exp. E, 15 Oct 2000, Ulrich 121 (Holotype B100293986); Balme, nahe Ahmetler sudwest 1. Murtiçi, 360 m, Exp. NW, 23 Apr 1997, Ulrich (paratype E00084587); near Ahmetler, crevices of limestone rocks, 330 m, Exp. N, 26 Aug 1998, Ulrich (Paratype E00077698).

\section{Acknowledgements}

We would like to thank Dr. G. Mitsainas for checking the English language of the manuscript. We are also grateful to the curators of the B, E, L, P and UPA herbaria for providing us with the comparative Potentilla material used in this study. Finally, we would like to thank the two anonymous reviewers for their useful comments, suggestions and corrections on an earlier version of this paper.

\section{References}

Ball, P. W., Pawłowski, B. \& Walters, S. M. 1968: Potentilla L. - Pp. 36-47 in: Tutin, T. G., Heywood, V. H., Burges, N. A., Moore, D. M., Valentine, D. H., Walters, S. M. \& Webb, D. A. (eds), Flora Europaea, 2. - Cambridge.

Baltisberger, M. 2006: Cytological investigations on Bulgarian phanerogams. - Willdenowia 36 (Special Issue): 205-216. doi: 10.3372/wi.36.36117

Boissier, E. \& Heldreich, Th. von 1856: Potentilla deorum Boiss. \& Heldr. - Diagn. Pl. Orient., s. 2, 2: 51. - 1872: Flora Orientalis, 2. - Genevae \& Basileae.

Contandriopoulos, J. 1962: Recherches sur la flore endémique de la Corse et sur ses origines. - Ann. Fac. Sci de Marseille 32: 1-354.

Dobeš, C. \& Paule, J. 2010: A comprehensive chloroplast DNA-based phylogeny of the genus Potentilla (Rosaceae): implications for its geographic origin, phylogeography and generic circumscription. - Mol. Phylogen. Evol. 56: 156-175. doi:10.1016/j.ympev.2010.03.005

—, Rossa, J., Paule, J. \& Hülber, K. 2013: Morphology, DNA-molecular variation, karyology, ecogeography, and phytosociology suggest allopatric differentiation and species rank for Potentilla rigoana (Rosaceae). - Taxon 62: 733-745. doi: 10.12705/624.8

Duman, H. \& Mill, R. R. 1999: Two new species of Potentilla L. (Rosaceae) from SW Turkey. Edinburgh J. Bot. 56: 349-354.

Eriksson, T., Donoghue, M. \& Hibbs, M. 1998: Phylogenetic analysis of Potentilla using DNA sequences of nuclear ribosomal internal transcribed spacers (ITS), and implications for the classification of Rosoideae (Rosaceae). - Pl. Syst. Evol. 211: 155-179.

-, Hibbs, M., Yoder, A., Delwiche, C. \& Donoghue, M. 2003: Phylogenetic of Rosoideae (Rosaceae) based on sequences of the internal transcribed spacer (ITS) of nuclear ribosomal and the trnL-F region of chloroplast DNA. - Int. J. Plant. Sci. 164: 197-211. doi: 10.1086/346163

Greuter, W. 2012: Results of the Seventh "Iter Mediterraneum" in the Peloponnese Greece, May to June 1995. - Bocconea 25: 5-127. doi: 10.7320/Bocc25.005

Halácsy, E. von 1888: Potentilla kionaea Halácsy. - Verh. K. K. Zool.-Bot. Ges. Wien 38: 751.

Iatroú, G. 1985: A new species of Potentilla (Rosaceae) from Peloponnesus, Greece. Candollea 40: 121-128. 
IUCN Standards and Petitions Subcommittee 2017: Guidelines for Using the IUCN Red List Categories and Criteria. Version 12. - Prepared by the Standards and Petitions Subcommittee. - Available at http://www.iucnredlist.org/documents/RedListGuidelines.pdf [Last Accessed: Feb 2017].

Juzepčuk, S. V. 1941: Potentilla L. - Pp. 78-223 in: Komarov, V. L., Siskin, B. K. \& Juzepčuk, S. V. (eds), Flora SSSR, 10. - Moskva \& Leningrad.

Kalpoutzakis, E. , Trigas, P. \& Constantinidis, Th. 2012: Allium orestis sp. nov. (Amaryllidaceae) from Parnon and Taigetos mountains, south Peloponnisos, Greece. - Nordic J. Bot. 30: 195200. doi: $10.1111 /$ j. $1756-1051.2011 .01490$

Kechaykin, A. \& Shmakov, A. 2016: A system of subtribe Potentillinae J. Presl (Rosaceae Juss.). Turczaninowia 19: 114-128. doi: 10.14258/turczaninowia.19.4.16

Kyriakopoulos, Ch., Liveri, E. \& Phitos, D. 2017: Campanula kamariana (section Quinqueloculares), a new species from S Peloponnisos, Greece. - Fl. Medit. 27: 131-135. doi: 10.7320/FlMedit27.131

Lundberg, M., Töpel, M., Eriksen, B., Nylander, J. A. A., \& Eriksson, T. 2009: Allopolyploidy in Fragariinae (Rosaceae): Comparing four DNA sequence regions, with comments on classification. - Mol. Phylogenet. Evol. 51: 269-280. doi: 10.1016/j.ympev.2009.02.020

Parolly, G. \& Nordt, B. 2002: A new chasmophytic species of Potentilla (Rosaceae) from S Anatolia, including some taxonomic remarks on P. subg. Fragariastrum in the E Mediterranean. Willdenowia 32: 73-83.

Pawłowski, B. 1965: De generis Potentilla L. serie Crassinerviae (Th. Wolf) B. Pawł. - Fragm. Florist. Geobot. 11: 53-91.

Peşmen, H. 1972: Potentilla L. - Pp. 41-68 in: Davis, P. H. (ed.), Flora of Turkey and the East Aegean Islands, 4. - Edinburgh.

Phitos, D., Constantinidis, Th. \& Kamari, G. (eds) 2009: The Red Data Book of Rare and Threatened Plants of Greece, 1-2. - Patras.

Potter, D., Eriksson, T., Evans, R., Oh, S., Smedmark, J., Morgan, D., Kerr, M., Robertson, K., Arsenault, M., Dickinson, T. \& Campbell, C. 2007: Phylogeny and classification of Rosaceae. - Pl. Syst. Evol. 266: 5-43.

QGIS Development Team, 2017: QGIS Geographic Information System. Open Source Geospatial Foundation Project. - http://qgis.osgeo.org [Last Accessed 24/11/2018]

Schiman-Czeika, H. 1969: Potentilla L. - Pp. 78-114 in: Rechinger, K. H. (ed.), Flora Iranica, 66. - Graz. Soják, J. 1987: Notes on Potentilla. IV. Classification of Wolf's group "Potentillae trichocarpae". Candollea 42: 491-500.

-, 2008: Notes on Potentilla XXI. A new division of the tribe Potentilleae (Rosaceae) and notes on generic delimitations. - Bot. Jahrb. Syst. 127: 349-358. doi: 10.1127/0006-8152/2008/0127-0349

Strid, A. 1986: Potentilla L. - Pp. 405-415 in: Strid, A. (ed.), Mountain Flora of Greece, 1. - Cambridge.

Tan, K. \& Iatroú, G. 2001: Endemic Plants of Greece: The Peloponnese. - København.

—, Siljak-Yakovlev, S. \& Vold, G. 2011: Geranium kikianum sp. nov. (Geraniaceae) from the southern Peloponnese, Greece. - Nordic J. Bot. 29(1): 1-5. doi:10.1111/j.1756-1051.2010.01028.x

Thiers, B. 2018+ [continuously updated]: Index Herbariorum: A global directory of public herbaria and associated staff. New York Botanical Garden's Virtual Herbarium. - Published at http://sweetgum.nybg.org/science/ih/ [Last Accessed 24/11/2018].

Wolf, Th. 1908: Monographie der Gattung Potentilla. - Bibl. Bot. 16 (71): 1-715.

Addresses of the authors:

Charalambos Kyriakopoulos ${ }^{1}$, Georgia Kamari ${ }^{1}$, Ioannis Kofinas ${ }^{2} \&$ Dimitrios Phitos ${ }^{1}$, ${ }^{1}$ Botanical Institute, Department of Biology, University of Patras, GR-26500 Patras, Greece. E-mails: hakyri@yahoo.gr; kamari@upatras.gr; dphitos@upatras.gr ${ }^{2}$ Ioannis Kofinas, Ilioupoleos Avenue 74, 17236 Imittos, Attiki, Greece. E-mail: kofinas@mani.org.gr 